\title{
UCHL5 Gene
}

National Cancer Institute

\section{Source}

National Cancer Institute. UCHL5 Gene. NCI Thesaurus. Code C158568.

This gene plays a role in deubiquitination, regulation of proteasome-mediated protein degradation and chromatin remodeling. 